\title{
Dariusz Śnieżko
}

\section{Dawni autorzy o grafomanii}

ABSTRACT. Śnieżko Dariusz, Dawni autorzy o grafomanii [Old Polish authors on graphomania]. "Przestrzenie Teorii" 8, Poznań 2008, Adam Mickiewicz University Press, pp. 143-160. ISBN 978-83-232187-5-3. ISSN 1644-6763.

The topic of the article are opinions formulated by old Polish writers on this sort of literary activity (and it's authors) that presently is called "graphomania", in the context of the ancient tradition and some statements expressed by selected European men of letters. At the beginning of the article theoretical conditions are sketched that - according to the author - should be taken into consideration in order to effectively use the terms "graphoman" and "graphomania". Then, on the basis of the literary quotations, there have been distinguished the criteria that in the old writers' eyes seemed the most representative of graphoman's works. In the end are presented the most popular, parodistic means used by the writers to discredit the title phenomena.

scribimus indocti doctique poemata passim Horacy, Epi. II, 1.

Bohaterem niniejszego szkicu jest grafoman, znany także jako wierszoman, wierszomaniak, wierszokleta, kleciowiersz, wierszorób, wierszarz, rytmopsuj, rymokleta, rymopleta, wierszobójca, metromaniak, wodolej, odolej, wersyfikalski, wersyfiksat, rymodziej, pseudopoeta, skryboman, bazgrała. Dodajmy, że również określenia: wierszopis czy rymopis, niegdyś opisowe i neutralne, w dzisiejszym użytku zabarwiły swoje znaczenia mało chwalebnymi konotacjami wierszoklety.

Kim jest ta osobliwa, skupiająca bogatą synonimię, figura, i jak ją rozpoznać? Grafomania jest rówieśnicą literatury pięknej, znaną każdej epoce. Znajomość ta bywa jednak dość powierzchowna i, by tak powiedzieć, intuicyjna. Wiemy doskonale, czym jest grafomania, gdy nas o to nie pytają. Jeśli zaś próbujemy poddać ten fenomen uporządkowanej refleksji, natomiast pojawiają się wątpliwości i kłopoty ${ }^{1}$. $\mathrm{Na}$ dodatek termin miewa różne zastosowania: występuje często jako krytycznoliteracka hiperbola, jako strategia prowokacji (tak Gombrowicz o Mickiewiczu), ale także, ze strony autorów, jako współczesny topos afektowanej

1 Usiłowałem zdać z nich, przynajmniej częściowo, sprawę w szkicu Fenomen grafomanii, albo na Hermenegildę Kociubińska paszkwil trzeci, „Pogranicza” 1997, nr 1. 
skromności: ktoś sam siebie nazywa grafomanem (często $\mathrm{z}$ mimowolną trafnością), spodziewając się gwałtownych zaprzeczeń.

Do niedawna grafomania nie była dla teorii literatury obiektem żywszego zainteresowania. Więcej uwagi poświęcali jej pisarze niż literaturoznawcy. Za autorytet $\mathrm{w}$ tej dziedzinie - sugerowany przez wyszukiwarki internetowe - uchodzi Milan Kundera, dzięki paru zręcznym akapitom w Księdze śmiechu $i$ zapomnienia. Owszem, wypowiadali się w sprawie grafomanii i badacze, ale - rzecz znamienna - tacy, który jednocześnie są praktykującymi literatami, jak Umberto Eco, czy Edward Balcerzan. Cykle zatytułowane Ksiażki najgorsze publikowali Antoni Słonimski i Stanisław Barańczak (drugi z nich to przecież nie tylko profesor, ale i uznany, nagradzany poeta). A dodać trzeba, że te publikacje są - w sensie gatunkowym - pociskami mniejszego kalibru. To przede wszystkim recenzje, felietony lub fragmenty powieści, tak jakby kwestia grafomanii była wstydliwym problemem rodzinnym samej literatury, uprzejmie bagatelizowanym przez tych zwłaszcza teoretyków akademickich, którzy wolni są od pisarskich ambicji. Monograficzny, poświęcony grafomanii numer poznańskiej „Polonistyki”2 przynosi kilka interesujących szkiców, co być może jest zwiastunem nadciągającej $\mathrm{z}$ wolna teoretycznej koniunktury, a być może tylko świadectwem chwilowego ożywienia.

\section{2}

W znanych mi próbach uchwycenia fenomenu grafomanii można z grubsza wyróżnić dwa stanowiska. Pierwsze wywodzi się z metod immanentnych (jak formalizm czy strukturalizm) i mogłaby mu patronować biblijna fraza „Po owocach ich poznacie je”. Według jego reprezentantów kryterium tekstowe uznaje się za wystarczające, zaś grafomania nie jest stanem twórcy, lecz dzieła. Zdaniem Edwarda Balcerzana rozpoznać ją można na podstawie uchwytnego badawczo rozejścia się zamiarów i realizacji. „Zamiar” także jest tu kategorią tekstową: to niespełniony postulat estetyczny, demaskowany przez wypaczone konwencje. Miało być wzniośle, a wyszło śmiesznie; miało być śmiesznie, a wyszło nudno ${ }^{3}$. W myśl podobnych ujęć grafomania staje się synonimem żenująco niskiego poziomu artystycznego. Jest to stanowisko metodologicznie jasne, wygodne i każdy filolog, który tekst uważa za swój dom, będzie

2 "Polonistyka” 2004, nr 8.

3 Zob. E. Balcerzan, Co znika dzisiaj, „Odra” 2000, nr 1; tenże, Grafomania projekt hasta encyklopedycznego, „Polonistyka” 2004, nr 8. 
podążał w jego stronę, bo tam jest u siebie. Oczywiście - wartość literacka może być przedmiotem sporu, ale przynajmniej dysponujemy specjalistycznym językiem do prowadzenia takiej dyskusji, sam zaś jej przedmiot jest wyraźny i latwo dostępny. Jest też chyba powszechna zgoda na to, że wyznacznikiem grafomanii jest artystyczna mizeria.

Ale - czy tylko ona? Inaczej mówiąc: czy estetyczna żenada tekstu automatycznie kompromituje autora jako grafomana? Weźmy dwa przykłady:

\footnotetext{
Natchnieniem poematów,

Żarem pomysłów dyszę,

Tyle przeróżnych tematów,

Więc ciągle piszę i piszę.
}

Co to mianowicie jest: grafomania? Być może. Być może nawet utwór ten został rozesłany do wszystkich pism literackich. Cóż jednak, jeśli to tylko pierwszy i ostatni zarazem wiersz w życiu? A jeśli nawet nie ostatni, to może nigdy nie zgłoszony do publikacji - przeznaczony do szuflady lub kosza? Może wreszcie został wyciśnięty z autora przymusem szkolnym? $\mathrm{Na}$ zajęciach z poetyki opisowej moi studenci mają obowiązek układać samodzielne, krótkie przykłady różnych formatów wersyfikacyjnych. To tylko takie ,jezuickie” (i skuteczne!) ćwiczenie akademickie, a nie konkurs poetyckiej piękności. Po przezwyciężeniu początkowych onieśmielen wszyscy (mam nadzieję) nieźle się bawimy i najsłabszego z tych studenckich przykładów nie ośmieliłbym się nazwać grafomańskim. Nie tylko z powodów grzecznościowych - bo czy można na kimś wymusić grafomanię, czy można w ogóle wymusić jakąkolwiek manię? Można wymusić tylko tekst. A sam tekst nie jest w stanie odpowiedzieć na zgłoszone wyżej pytania.

Rozważmy drugi przykład:

Przyjaciel wierny więcej znaczy

Niż skarb niezmierny. On przebaczy

Wszystkie urazy

Kilka razy.

A jeśli jesteś w potrzebie,

Idziesz do niego jak do siebie,

On tobie pożycza,

Pieniądze odlicza.

A jeśli masz jakie zgryzoty,

Czy to zmartwienie, czy kłopoty,

U niego pociechy szukasz,

Do jego serca pukasz...

Czy to grafomania? Rozejście się zamiarów i rezultatów jest oczywiste: miał być wzruszający wiersz o przyjaźni, a wyszła mimowolnie ko- 
miczna poczwara wersyfikacyjna. Wyznaczniki tekstowe w przedstawionym wyżej rozumieniu są spełnione: wydaje się więc, że tak, to grafomania. Ale spełni je - zauważmy - także p a r o d i a grafomanii, która zresztą w rezultacie zawsze okazuje się p a $\mathrm{s}$ t i s z e m, bo dzieło grafomańskie „samo z siebie" jest już wyposażone w cechy mimowolnie komiczne. Oba cytowane przykłady są zabawne, jednak tylko drugi z nich jest taką właśnie parodią i pochodzi z noweli Bolesława Prusa pt. Kłopoty redaktora ${ }^{4}$. Przykład pierwszy natomiast to szczera - jak można podejrzewać - grafomania (wiersz z antologii poezji polonijnej5). A przecież - uwaga - można by tę atrybucję zamienić, bez większego oporu ze strony obydwu tekstów. Oczywiście, w przypadku noweli kontekst, w jakim wiersz się pojawia, jest wystarczający, by go zdemaskować jako parodię, ale historia literatury notuje przykłady (będzie o nich mowa niżej) znacznie bardziej kłopotliwe: parodie pisywane przez uznanych autorów, a dla żartu ogłaszane pod imieniem znanych grafomanów, i trzeba szczegółowej wiedzy pozaliterackiej, by orzec, kto w końcu jest autorem - same wyznaczniki tekstowe okazują się bowiem zawodne.

Wydaje się więc, że nieudolność jest grafomanii warunkiem koniecznym, ale niewystarczającym. Tak, jak w medycynie: jeden symptom może wskazywać na różne schorzenia. Podobnie koślawy tekst: może wskazywać - oprócz grafomanii - na świadomy, merkantylny kicz, wymuszone zadanie szkolne czy pensjonarskie wyznanie zanotowane $\mathrm{z}$ „potrzeby serca".

Otóż drugie z zapowiedzianych stanowisk metodologicznych wywodzi grafomanię z osobliwej a niezdrowej dyspozycji psychicznej (np. „chorobliwą" potrzebę pisania bierze pod uwagę Stownik terminów literackich). Od czasów starożytnych potoczna intuicja widzi w grafomanach niegroźnych szaleńców. Jak się wyraził Julian Tuwim, „Bzik niegroźny, raczej miły, ale zawsze bzik"6. Ale z drugiej strony równie długa tradycja (by przypomnieć Platońskiego Iona) twórczość artystyczną, a może zwłaszcza tę wybitną, łączy z jakąś postacią dewiacji. Kazimierz Dąbrowski pisał niegdyś elegancko o „dezintegracji pozytywnej”, ale samym pisarzom jest latwiej rzeczy nazywać wprost (jak Andrzejowi Stasiukowi, wedle którego każde pisanie jest „bardziej lub mniej łagodną odmianą pierdolca"7).

Powiedzmy więc od razu za Grzegorzem Giedrysem, że „Międzynarodowa Statystyczna Klasyfikacja Chorób i Problemów Zdrowotnych

4 W: B. Prus, Nowele, t. 1, Warszawa 1966, s. 270.

5 Wydaje mi się, że dane bibliograficzne nie są w tym wypadku konieczne.

${ }^{6} \mathrm{~J}$. Tuwim, Pegaz dęba, Warszawa 1950, s. 16.

${ }^{7}$ Cyt. za: G. Giedrys, Choroba na pisanie. Grafomania w ujęciu psychologicznym i psychiatrycznym, „Polonistyka” 2004, nr 8, s. 5. 
(ICD-10), opracowana przez Światową Organizację Zdrowia, nie rozpoznaje odrębnej jednostki chorobowej, noszącej nazwę grafomanii"8. A żadna $\mathrm{z}$ kwalifikowanych jednostek także nie znajdzie tu dobrego zastosowania: ani różne odmiany $\mathrm{z}$ dziedziny psychopatologii nerwic, ani zespół psychopatii osobowościowej. Wprawdzie psychopatia prowadzi do osobowościowych cech antyspołecznych rozwiniętych na gruncie nasilonego narcyzmu, a i grafoman pozostaje poza marginesem aktualnie wiążących norm literackich, ale - dodajmy - raczej nie dlatego, że je kontestuje, tylko dlatego, że za nimi nie nadąża; poza tym „psychopatyczna” kontestacja zastanych norm jest właściwa także dla przedsięwzięć odkrywczych, bez których jakikolwiek proces historycznoliteracki byłby nie do pomyślenia.

Do rozważenia jest natomiast szczególna potrzeba psychiczna, o której pisze Milan Kundera: „Kobieta, która pisze do swego kochanka cztery listy w ciągu dnia, nie jest grafomanką, lecz zakochaną kobietą. Ale mój przyjaciel, który sporządza fotokopie swej miłosnej korespondencji, żeby móc ją opublikować, jest grafomanem. Nie jest grafomanią pragnienie pisania listów, dzienników, kronik rodzinnych (a więc dla siebie lub swych najbliższych), lecz jest nią pragnienie pisania książki (czyli posiadania publiczności, nieznanych czytelników). Pod tym względem namiętność taksówkarza i Goethego jest identyczna. To, co odróżnia Goethego od taksówkarza, nie jest inną namiętnością, lecz tylko innym skutkiem tej namiętności"9. W cytacie są do zauważenia dwie rzeczy: charakterystycznym rysem osobowości grafomańskiej jest nieodparty przymus publikacji, ale zarazem namiętność ta (poniekąd wspólna dla grafomanów i rzetelnych pisarzy) staje się grafomańska wówczas dopiero, gdy bierze górę nad estetyczną samokontrolą. Kryterium estetyczne pozostaje w mocy, ale pod warunkiem uruchomienia go w pewnym kontekście psychospołecznym. Dolą grafomana jest, jak się ktoś wyraził, pusta forma bycia pisarzem - pusta, bo grafoman nie ma nic do powiedzenia, nie ma też swojego języka, w którym mógłby cokolwiek wyrazić, i nie jest to zresztą jego zmartwieniem. Chodzi mu tylko o to, by społecznie zaistnieć w roli pisarza. O to, by karmić swój narcyzm.

Powtórzę ${ }^{10}$ : krzywe zwierciadło grafomanii karykaturalnie wyolbrzymia potoczne stereotypy poety, przebrzmiałe mitologie artysty. Gdy grafoman z dumą komunikuje siebie jako poetę, otacza się peleryną, którą wygrzebał drągiem $\mathrm{z}$ literackiego śmietnika. W rezultacie - jak się zdaje - grafomanię identyfikują: po stronie podmiotu niekontrolowany

\section{Tamże.}

${ }^{9}$ M. Kundera, Księga śmiechu i zapomnienia, przeł. P. Godlewski i A. Jagodziński, Warszawa 1993, s. 97-98.

${ }^{10}$ Nawiązuję tu do mojego szkicu wskazanego wyżej. 
narcyzm (cokolwiek by nie powiedzieć o grafomanach, oni i tak tego nie biorą do siebie), udokumentowany publicznie co najmniej natarczywą chęcią publikowania (a często jest to publikacja „nakładem własnym autora"11), po stronie gatunkowo-stylistycznej: epigonizm i tandeta (więc i banal w sferze komunikowanych światu idei). Zarazem podkreślmy jeszcze raz: żaden $\mathrm{z}$ tych warunków, bez pozostałych, nie wystarczy: trudno o artystę nie naznaczonego narcyzmem, a i nie każde epigoństwo, nie każdy banał wskazuje na grafomanię.

Grafomania łatwo bowiem traci tożsamość w sąsiedztwie zjawisk, wydawałoby się, pokrewnych. Rozważmy oto stosunek grafomanii do kiczu. Pojęcia te bywają niekiedy utożsamiane, podczas gdy pod paroma względami układają się wręcz w opozycję przeciwstawną. Andrzej Skrendo, analizując dzisiejszy rynek literacki, pisze o "grafomanii podniesionej", wskazując na wiele współczesnych poczytnych, a jednak bardzo marnych powieści12. A przecież nie pisze on - moim zdaniem - o grafomanii, tylko o kiczu. Jedno i drugie charakteryzuje się mizerią estetyczną, ale: grafomania dąży do utrwalenia sygnatury autorskiej - kicz jest często skrywany pod pseudonimem lub zgoła anonimowy; grafomania ma poświadczyć indywidualność - kicz jest rezultatem taśmowej (czasem dosłownie) produkcji; grafoman chętnie dołoży do publikacji swoich utworów - kicz jest wytwórczością obliczoną na zysk ( $w$ tym samym stopniu ogrodowy krasnal, co kilka strofek przeplatanych refrenem „O dziewczyno ma, gdzie jest miłość twa”). Grafomania jest naznaczona swoistym heroizmem, kicz jest ze swej natury oportunistyczny. Grafomania to bezkompromisowy gest narzucenia się publiczności - kicz jest elastyczną odpowiedzią na popyt; owszem, może go przez jakiś czas kreować, wzmacniać, ale zaniknie wraz z malejącym zapotrzebowaniem. Jeden przykład, chcąc nie chcąc wszystkim znany ze słyszenia: teksty do piosenek disco polo były - jeśli dobrze pamiętam - w większości anonimowe, w każdym razie autorom chyba nie zależało na rozgłosie. Masowo produkowane, masowo kupowane, miały przynosić dochód. To wszystko się skończyło wraz z wygaśnięciem popytu.

$\mathrm{Z}$ tych samych powodów grafomania nie jest tożsama $\mathrm{z}$ literaturą brukową, straganową, wagonową, jarmarczną, pornograficzną - każda $\mathrm{z}$ nich jest bowiem uzależniona od mechanizmów konsumpcji. Ponadto grafomania owszem, jest epigońska, ale nie każdy epigon jest grafomanem. Co więcej, grafomania narażała się na szczególnie bezwzględne drwiny właśnie ze strony epigonów, jeśli za takich zechcemy uznać przedstawicieli tzw. klasycyzmu warszawskiego.

11 W której ambicje autora spotykają się z interesem wydawcy, co zabawnie przedstawił U. Eco w powieści Wahadto Foucaulta.

12 A. Skrendo, O dziele grafomańskim, „Polonistyka” 2004, nr 8, s. 15. 
Reasumując powyższe uwagi, uznać trzeba, że grafomania jest zjawiskiem, które nie da się adekwatnie opisać w języku analizy tekstu. Paradoksalnie - jej precyzyjne narzędzia, jeśli nie współpracują z inny$\mathrm{mi}$, są w stanie uzasadnić jedynie potoczne użycia terminu, jak to się dzieje wówczas, gdy po lekturze czegoś słabego parskniemy z irytacją "toż to grafomania". Ta jednak - w całym swym tragikomicznym splendorze - jest uchwytna dopiero na pograniczu analizy tekstu, psychologii (czy psychopatologii) i socjologii literatury. A zresztą - jak dotąd, wypowiedzi na temat grafomanii najczęściej są w istocie rzeczy wypowiedziami na temat grafomanów i ich tęsknot. Tak też przedstawia się tradycja staropolska, w zgodzie z podmiotowym nastawieniem, najogólniej mówiąc, ówczesnej praktyki krytycznoliterackiej ${ }^{13}$.

\section{3}

Autorzy dawni nie znali terminów „grafoman”, „grafomania”. Termin "grapho-maniac" najwcześniej pojawił się w Anglii w 1827 r. Słowo "grapho-mania" tamże w roku 1840. Polski „grafoman” (jako skrót od grafomaniak) wchodzi do obiegu w 1899 r., (w „Tygodniku Ilustrowanym”, ale już Sienkiewicz w r. 1901 obdarzył nim Wyspiańskiego po premierze Wesela). Natomiast nazwa "grafomania" zasila polską terminologię literacką dopiero w 1 . poł. XX wieku' ${ }^{14}$. Autorzy dawni z konieczności posługiwali się terminami wówczas nienacechowanymi negatywnie (wieszcz, poeta, rymopis), które dopiero kontekst zabarwiał ironicznie.

Już z zamieszczonego na wstępie przeglądu terminologii wynika, że wiersz, poezja są uznawane za szczególnie zagrożone grafomanią. Nie dysponuję też żadnym przykładem staropolskiego autora, który grafomana rozpoznałby w prozaiku. Wspominało się o poetach, a od wieku osiemnastego - także o dramatopisarzach, ale i oni pisali swoje sztuki wierszem. Dlaczego tak jest? Na ten wątpliwy przywilej poezji, jakoś szczególnie wabiącej grafomanów, zwróciła uwagę także Katarzyna Szewczyk, a tłumaczy go tym, że wzorce liryczne łatwiejsze są do naśladowania i dlatego masowo padają ofiarą grafomanów ${ }^{15}$. Moim zdaniem ten stan rzeczy można wyjaśnić zupełnie inaczej: przez długie stulecia literatura piękna utożsamiana była z poezją, z mową wiązaną. Proza, wyjątkowo kodyfikowana w europejskich poetykach normatywnych, wszędzie doj-

13 E. Sarnowska-Temeriusz, T. Kostkiewiczowa, Krytyka literacka $w$ Polsce $w$ XVI $i$ XVII wieku oraz w epoce oświecenia, Wrocław 1990, s. 106-107.

14 Zob. A. Bańkow ski, Stownik etymologiczny języka polskiego, t. 1, Warszawa 2000 (hasto "Grafoman").

15 K. Szewczyk, Czym jest grafomania?, „Polonistyka” 2004, nr 8, s. 18. 
rzewała dłużej. A jeszcze Prus poezję czyni przedmiotem grafomańskich aspiracji, podobnie Dostojewski w Biesach, bo w XIX stuleciu wiersz ciągle uchodził za formę szlachetniejszą - wówczas to namiętnie wersyfikowano nawet te gatunki, które od dawna dojrzały do prozy: Wincenty Krasiński wydał w 1859 r. dzieje narodu polskiego wierszem, na sześciuset stronach. A i dzisiaj, myśląc o grafomanii, odruchowo myślimy najpierw o pseudopoetach; poetą jest też przekomiczna figura (nie wiem, czy autentyczna) z Rejsu Marka Piwowskiego.

Dzieje się tak, bo w potocznej opinii wiersz jest wyposażony w znacznie od prozy silniejsze wyznaczniki literackości. Także pewnie dlatego, że w prozie - jak zauważył Eliot - w ogóle mniej absorbuje nas hierarchia. Najpierw w obiegu oficjalnym, wysokoartystycznym, później tylko na gruncie opinio communis, ale bodaj czy nie po dziś dzień, status poety był uznawany za status wyższy, odświętny, kojarzony $\mathrm{z}$ wtajemniczeniem, boskim szałem, natchnieniem, uczonością ( $w$ ujęciach staropolskich), później bywał łączony z posłannictwem romantycznego wieszcza czy wyniosłą legendą poety przeklętego. A to wszystko uświetniały tradycyjne atrybuty, jak lira, wieniec laurowy, kaduceusz, peleryna, a także pewne społeczne przywileje czy licencje, wynikające choćby z osobliwie nobilitujących „wariackich papierów”. To poeta, nie prozaik, występował w przebraniach Orfeusza, Tyrteusza, Prometeusza, on więc przede wszystkim bywał obiektem grafomańskich ambicji. Grafoman bowiem zwykle nie zadowala się niższą grzędą, od razu gramoli się na Parnas ten zaś był zamieszkały głównie przez poetów. Oczywiście im poprzeczka wyżej, tym i kompromitacja większa. Jak pisał nieoceniony Montaigne: „Można być niezdarą we wszystkim na świecie, ale nie w poezji" 16 .

W przypadku kultury dawnej brak terminologii nie jest jedynym problemem i nie najmniejszym. Specyfika życia towarzyskiego, szkolnictwa i rynku wydawniczego epok dawnych, egalitaryzacja literatury, zacierają kontury zjawiska i rozmywają jego ostrość. W siedemnastym wieku poetyki powszechnie już uczono w kolegiach, wyposażając wychowanków w kompetencję typu użytkowego. Ani zatem ćwiczenia szkolne, ani bujnie pleniący się panegiryzm na skalę krajową i powiatową, raczej nie dostarczają dobrych przykładów, chyba że $\mathrm{z}$ tych instytucjonalnych (w szerokim sensie) furtek korzystało się głównie dla zaistnienia w roli poety. Panegiryzm z grafomanią połączyło oświecenie (zwłaszcza Węgierski w Liście do wierszopisów). Rzecz znamienna: dopiero wtedy nowoczesna figura grafomana wkracza do życia literackiego, bo w warunkach polskich dopiero wówczas powstaje instytucja salonu, elitarnego

16 M. de Montaigne, Próby, ks. 2, przeł. T. Żeleński (Boy), oprac., wstępem i komentarzem opatrzył Z. Gierczyński, Warszawa 1985, s. 306. 
zgromadzenia znawców rozpoznających i piętnujących grafomanów, zresztą do tego właśnie salonu aspirujących. A grafomania, po to, by zaistnieć jako zjawisko społeczne, potrzebuje właśnie salonu, czyli aktu oceny i gestu wykluczenia. I jeśli wieki XVI i XVII były łaskawe dla grafomanów, otaczając ich dyskretną anonimowością (chodziło raczej o kompromitację samego zjawiska), to dobę stanisławowską opromienią imiona Józefa Bielawskiego, Marcina Molskiego, Jacka Przybylskiego, a także w tej roli, choć z oczywistą krzywdą, Józefa Baki; nieco później pojawi się biedny Jaksa Marcinkowski, nieświadomy błazen salonu generała Wincentego Krasińskiego czy hr. Kiszka Zgierski, znany grafoman wileński.

Przeciwstawia się czasem grafomanię literaturze ${ }^{17}$, podczas gdy grafomania jest już przecież zjawiskiem literackim; literatura, również dzisiaj, przypomina kamienicę, w której są sutereny i są salony. Grafomania nie jest biegunem przeciwnym literaturze jako takiej, lecz literackiemu salonowi, do którego, niezrażona odmową, natarczywie usiłuje się dostać, w którego przedpokojach wystaje. Bywają marni poeci, ale mają swoją wierną, niewymagającą, najczęściej lokalną, powiatową, publiczność. Jeśli znają swoje miejsce, jeśli w tych suterenach potrafią się jakoś urządzić i nie wdzierają się gwałtem na wyższe piętra, etykieta grafomana byłaby chyba dla nich zbyt krzywdząca. Nie jest też chyba „bastionem grafomanii" internet ${ }^{18}$ i cała ta blogowa pisanina. Sfera, w której każdy może publikować, jest dla grafomana rajem tylko na pozór, zaś w istocie rzeczy - piekłem anonimowości. Pozostać jednym z setek tysięcy blogerów - to dla grafomana raczej ponura perspektywa. Internet jest egalitarny, grafomania nie może żyć bez hierarchii; internet zaciera granice pomiędzy pismem i głosem, grafomania już w samej swojej nazwie wyróżnia piśmienne utrwalenie. Prawdziwy grafoman nie bloguje (i nie umieszcza wierszy na stronie domowej) po to, żeby się wypisać, tylko jeśli już się pojawia, to $\mathrm{z}$ nadzieją na zaproszenie do prawdziwego salonu (,może mnie zauważą?"), bo przecież krytycy, badacze literatury także do sieci zaglądają.

\section{4}

Zapytajmy wreszcie, jakie symptomy tego, co dzisiaj nazywamy grafomanią, rozpoznawali nasi przodkowie. Nie tylko dla porządku warto je podzielić na wyznaczniki podmiotowe (grafomański autor) i przedmioto-

${ }_{17}$ Tak np. A. Skrendo, op. cit.

18 Tu znów muszę się nie zgodzić z moim znakomitym kolegą. Por. A. Skrendo, op. cit., s. 15 . 
we (grafomański tekst). Powiedzmy od razu, że pierwsze są znacznie liczniejsze, zgodnie zresztą z profilem większości poetyk normatywnych, które częściej były poradnikami dla autora niż analizami tekstu.

Pierwszorzędną cechą grafomana okazuje się INSANIA, czyli szaleństwo. O szaleństwie nieudolnych poetów wyrozumiale pisał Horacy w Liście I, 1, a także - ostrzej - w Sztuce poetyckiej. Juwenalis w satyrze VII powiada o złym nałogu, który wierszokletę trzyma na powrozie. Jeden z bohaterów Satyrykonu Petroniusza, Eumolpus, cierpi na chorobliwy przymus deklamowania swoich poematów przy lada okazji. „Proszę cię, cóż ty sobie myślisz z tą swoją chorobą? - mówi doń Eukolpus Jeszcze dwóch godzin ze mną nie jesteś, a więcej mówiłeś po poetycku niż po ludzku"19. O niebezpiecznej żądzy wspominał jeszcze Boileau w Sztuce rymotwórczej, a spośród rodzimych autorów na wewnętrzny przymus pisania czegokolwiek wskazywał ironicznie Łukasz Opaliński [Coś nowego].

W bezpośrednim związku $z$ insanią pozostaje NARCYZM. Jako jeden z pierwszych demaskował go Marcjalis pisząc, że nikt tak sobie nie ufa, jak lichy poeta [XII, 63, 13]. Motyw rozwinął Erazm z Rotterdamu w Pochwale glupoty:

A cóż dopiero wspominać o wyznawcach sztuk wyzwolonych, skoro tak właściwa im wszystkim sobiemiła Filautia, że łatwiej znalazłbyś wśród nich kogoś, kto by ustąpił swej ojcowizny niż tytułu wyższości swego talentu, co zwłaszcza odnosi się do komediantów, śpiewaków, mówców i poetów, którzy im mniej umieją, tym przesadniej z siebie zadowoleni i tym bardziej się chełpią i puszą ${ }^{20}$.

\section{A podobnie Montaigne:}

Znam wierszokletę, któremu mali i duzi, na rynku i w domu, niebo i ziemia krzyczą, że nie ma pojęcia o swym rzemiośle: nie opuszcza mimo to ani cala $z$ miary, jaką sobie wykroił. Ciągle zaczyna na nowo, ciągle się radzi, ciągle upiera się, tym silniejszy w swym zdaniu i tym bardziej niezłomny, im bardziej w nim osamotniony ${ }^{21}$.

\section{Łukasz Górnicki pisał w Dworzaninie:}

A co rozum człowieczy a rozsądek dla wiela przyczyn niedobrze dojrzy, to dopiero, kiedy wstąpi w nas chciwość zbytnia czestki, prawie nic nie widzi, bo każdy rad się z tym popisuje, co rozumie o sobie, iżby umial, mało się o tym pytając, tak-li jest, czyli nie, jako o sobie rozumie 22 .

19 Petroniusz, Satyryki, przeł. i oprac. M. Brożek, Wrocław 1968, s. 109.

20 Erazm z Rotterdamu, Pochwata glupoty, przel. i oprac. E. Jędrkiewicz, wstęp

H. Barycz, Wrocław 1953, s. 82-83.

21 Tamże, s. 307.

22 Ł. Górnicki, Dworzanin, oprac. i wstępem zaopatrzył R. Pollak, Warszawa 1950, s. 75 . 


\section{Z brakiem samokontroli wiązał narcyzm Wacław Potocki [Moralia,}

II, 549]:

Aż ów: „Dziś dzień czwarty,

Pełne ich w dwu seksternach po obu stron karty.

Same płyną; nie masz w nich i jednej litury.

Nie uczywszy się, znać, żem poetą z natury".

„Wszytkie li takie, jak te, nie masz podziwienia:

Więcej piasku w garść weźmie niż na wóz kamienia ${ }^{23}$.

Ten sam Potocki zauważył jednak trzeźwo:

[...]

Wszyscy z natury w jednej leżymy chorobie,

Że jak w dzieciach, w piśmiech swych podobamy sobie:

Chwalimy, choć leda co, choć wielkie nic k rzeczy;

$\mathrm{Na}$ wieki nieprzyjaciel, kto gani, kto przeczy.

[Odjemek od herbów szlacheckich. Przedmowa $]^{24}$

Znane są przykłady grafomanów, którzy (jak np. Kiszka Zgierski25) nigdy nie wierzyli krytykom. Ale - nikomu nie przychodzi to łatwo.

Za kolejny atrybut grafomana uznałbym, wraz $\mathrm{z}$ dawnymi pisarzami, AUTOKREACJĘ zmierzającą do zyskania społecznego statusu poety. Chodzi tu przede wszystkim o pozy, miny, stroje, zachowania (zwłaszcza symulowane szaleństwo), które w oczach innych z grafomana mają uczynić poetę. Francesco Robortello [Paraphrasis in librum Horatii, qui vulgo „De arte poetica ad Pisones”] nawiązywał do znanego motywu:

Tenże Demokryt sądził, że nie należy zaliczać do grona poetów ludzi, którzy nie powodują się jakimś szałem [furor] i są przy zdrowych zmysłach. Dlatego możesz zauważyć, że wielu ludzi, którzy starają się uchodzić za poetów, zapuszcza brodę, nie obcina paznokci, szuka samotności, unika interesów i spraw publicznych oraz łaźni, ażeby właśnie uważano ich za szalonych ${ }^{26}$.

Takie uzurpacje poirytowały naszego Andrzeja Krzyckiego:

Toż teraz wiersze pisać chciałby nawet rabuś,

Co poborcą podatków raczej winien być.

$\mathrm{Z}$ tego sobie tytułu purpurowe szaty

Już gotuje i pychą tym większą się dmie.

${ }^{23}$ W. Potocki, Moralia $i$ inne utwory $z$ lat 1688-1696, oprac. L. Kukulski, Warszawa 1987 , s. 339.

${ }^{24}$ Tamże, s. 478.

${ }_{25} \mathrm{~W}$. Bełza, Wierszokleta, w: Encyklopedia humoru $i$ satyry polskiej, t. IV, red. A. Orłowski, Warszawa 1914, s. 131.

${ }^{26}$ F. Robortello, Paraphrasis in librum Horatii, qui vulgo „De arte poetica ad Pisones” inscribitur (Parafraza ksiegi Horacego pospolicie nazywanej „O sztuce poetyckiej do Pizonów”), w: Źródła wiedzy teoretycznoliterackiej $w$ dawnej Polsce. Średniowiecze - Renesans - Barok, wstęp, wybór i oprac. M. Cytowska i T. Michałowska, Warszawa 1999, s. 339. 
Na stryczku by go zrobić podwójną literą,

By innych do rzygania nie wiódł jego wiersz.

Kto chce żółć sobie ulać, by zyskać apetyt, Śmierdzące niechaj wieszcza czyta karty dziel

[Apollo do czytelnika [27

A podobnie srożył się Krzycki w wierszu Rzeczpospolita do swych poetów. Utwór poświęcony temu zagadnieniu znajdziemy w także w Moraliach Wacława Potockiego [II, 534]:

„Wino koniem poetom." Ledwie go w brzuch nalał,

Rzekłbyś, że od rozumu odszedł, będzie szalał.

Nie inszą znać przyczynę uważał, ale tę,

Kto nazwał po łacinie epotą poetę.

Biega, palcami trzaska i rękami chwieje,

Abo czoło posępi, abo z sobą śmieje.

W sobie, niż na papierze, pokaże sam pierwej

Kunszt w słowach i w dowcipie éwiczonej Minerwy,

[...]

Siłuż pseudopoetów ta się i dziś imie,

Ze jako, choć plugawe, sowy chwalą dzieci,

Tak ci wiersze swe uszu niegodne poeci28.

Oczywiście wśród cech rozpoznawczych grafomana nie mogło zabraknąć NIEKOMPETENCJI (negatywny odpowiednik kategorii ars) i BEZTALENCIA (negatywny odpowiednik kategorii ingenium). Horacy narzekał, że uczeni i nieuczeni powszechnie piszą poematy, "Nie pozwolą jednakże poecie / Być miernym bóstwa, ludzie ni półka księgarza"29. O umiejętności upominał się Łukasz Opaliński:

Tegoć nie pomnię, bym Helikonowę

Wodę miał pijać albo Parnasowę

Górę nawiedzał, gdzie kto przemieszkiwa,

Choć nic nie umie, snadź poetą bywa.

Nie znam się nawet i z tymi. Muzami,

Które tych wszystkich czynią poetami,

Co ich wzywają; ja to mam za baśnie,

Aby co darem przyńść mogło i właśnie

Jakobyś znalazł; za pracą Bóg dawa

Wszytko, jako to ktoś mądry przyznawa.

27 A. Krzycki, Poezje, przeł. E. Jędrkiewicz, oprac. i wstępem opatrzyla A. Jelicz, Warszawa 1962, s. 90.

28 Tamże, s. 327.

${ }^{29}$ K. Horacjusz Flakkus, Sztuka poetycka, w tegoż: Dzieła wszystkie, t. 2, Gawędy. Listy. Sztuka poetycka, tekst łaciński do druku przygotował, wyboru przekładów dokonał, komentarzem opatrzył O. Jurewicz, Wrocław 1988, s. 458. 
Chyba, żeby ten miał być pisorymem,

Co sobie głupiej fantazyjej dymem

Głowę zarazil i już tak rozumie,

Że wiersze pisać bardzo dobrze umie ${ }^{30}$.

W podobnym duchu kilkakrotnie wypowiadal się w Moraliach Potocki, biadając nad rozpowszechnianiem się ambicji literackich wśród dam - osób nieuczonych, więc niekompetentnych.

Natomiast brak talentu („ducha Boskiego") wypominał nieudolnym rymopisom Stanisław Serafin Jagodyński [w Dworzankach]:

\section{Poeta:}

Nie to poeta, co tym sławi się, ani to,

Co łakomie zagarnął poetyckie myto.

Nie to poeta (bo to plota) co rymuje rymem, Co mu ślina przyniesie, parą ginie $\mathrm{z}$ dymem.

Nie to poeta (bo to bachur), co też baje;

To poeta, komu Bóg ducha swego daje.

Bo duszę rzeczom dawać, tworzyć co z niczego

Trzeba mowy do tego i ducha Boskiego ${ }^{31}$.

Umówiliśmy się jednak, że brak uzdolnień nie wystarczy, by zostać mianowanym na grafomana. Dlatego za wyznacznik kolejny, bardzo istotny, wypada uznać NATARCZYWOŚ́ zmierzającą do publikacji w jakiejkolwiek formie. Może to być tylko namolność prywatna rozpoznana przez Horacego w satyrze I, 9 czy Marcjalisa [V, 73], ale i ta zwykle bywa tylko etapem na drodze, której celem jest jak najszersze rozpowszechnienie własnej twórczości, bo - zacytujmy I satyrę Persjusza „któż by nie chciał być na ustach ludu"32. Zbigniew Morsztyn w Przestrodze poprzedzającej Muzę domowa przekornie zniechęcał do czytania własnych wierszy, bo nie ma w nim tej ambicji, jak u tych, co „byle tylko wiersze pisali po składzie - ści - ści, - go - go, to z nimi do druku, choćby się wiersza, jako mówią, racy nie jęli i choć mizerna Muza skrzypiąc się wlecze jak ruska kolaska"33.

Bardzo widocznym znakiem rozpoznawczym grafomana była też NADPRODUKTYWNOŚĆ. W Antologii Palatyńskiej znajdziemy utwór Lukilliosa, pod tytułem Eutychides $w$ Hadesie:

${ }^{30}$ L. Opaliński, Poeta nowy, w: I w odmianach czasu smak jest. Antologia polskiej poezji epoki baroku, oprac. J. Sokołowska, Warszawa 1991, s. 354.

31 Poeci polskiego baroku, oprac. J. Sokołowska, K. Żukowska, t. 1, Warszawa 1965, s. 345 .

32 Trzej satyrycy rzymscy. Horacy - Persjusz - Juwenalis, wstęp i komentarz w opracowaniu L. Winniczuk, Warszawa 1958, s. 97.

33 Z. Morsztyn, Muza domowa, oprac. J. Dürr-Durski, t. 1, Warszawa 1954, s. 101. 
Umarł Eutychides, poeta liryczny. Zmykajcie,

Wy tam pod ziemią! On niesie swoje ody.

Nakazal, by razem z nim dwanaście cytr spalono

I dwadzieścia pięć kufrów jego utworów muzycznych.

Zaiste Charon was dopadł. Dokądże teraz ktokolwiek

Ucieknie, gdy Eutychides i Hadesem zawładnął? ${ }^{34}$

A i horacjański wierszokleta chwalił się [Satyra I,9]: „Boć przecież któż skrobnie / Tyle wierszy za jednym zamachem?” - „nam quis me scribere pluris aut citius possit versus?" 35 . W satyrze I, 10 (krytycznej wobec Lucyliusza) pojawi się postać Kasjusza Etruscusa, płodnego grafomana, którego zwłoki spalono ponoć na stosie utworzonym $\mathrm{z}$ jego książek. O płodności grafomańskiej wspominali też Persjusz (V) i Juwenalis (I). Właściwie każda epoka zna ten motyw. W wieku dwudziestym na nadprodukcję książek narzekał m.in. Gombrowicz, narzekal Konwicki. Ale problem był znany już Lubomirskiemu [Rozmowy Artaksesa i Ewandra], Potockiemu [Moralia I, 1, 37] czy Ignacemu Krasickiemu, którego zdaniem to druk wypromował „nudne muzy, a niezmiernie płodne" [Pochwata wieku ${ }^{36}$.

Mnogość książek miała związek z mnogością płodnych jak króliki (określenie W. Potockiego) autorów. LICZEBNOSC grafomanów będzie zatem kolejnym wyznacznikiem identyfikującym zjawisko. Wskazuje ona bowiem na upadek standardów jakości. Pierre de Ronsard (Zarys francuskiej sztuki poetyckiej przesłany Alfonsowi Delbene opatowi Hautecombe $w$ Sabaudii) pisał, że poeci rzymscy rozmnożyli się jak mrówki, przynosząc bibliotekom więcej ciężaru niż honoru. Angielski koneser poezji i teoretyk, Wiliam Webbe, na początku Rozprawy o poezji angielskiej biadał nad mrowiem książek i broszur, ,jakie trapią nasz kraj, zapychają wszystkie księgarnie i zapychają wszystkie gabinety"37. Najbardziej reprezentatywnym polskim przykładem jest znany fragment sielanki $W i$ niarze Bartłomieja Zimorowica:

Tak to jest, że co żywo wierszyki partoli, Ale niepłatne, jako kiedy kto na roli, Choć dobre ziarna, tylko że gęsto zasieje,

Drobny urodzaj miewa; tak się teraz dzieje:

Pełna niedoszłych nasza poetów ojczyzna, Że miary zawierszona nie ma już polszczyzna;

${ }^{34}$ Antologia Palatyńska, wybral, przeł. i oprac. Z. Kubiak, Warszwa 1992, s. 142.

${ }^{35}$ Tamże, s. 106.

${ }^{36}$ I. Krasicki, Satyry i listy, wstęp J. T. Pokrzywniak, oprac. tekstów i komentarze Z. Goliński, Wroclaw 1988, s. 102.

${ }_{37}$ Źródta wiedzy teoretycznoliterackiej $w$ dawnej Polsce, s. 421. 
Lada partacz wyrwie się z pospolitych ludzi,

To wiersze niepoczesne natychmiast paskudzi.

Przedtym rzadki kto Muzy jak świątości ruszył,

Tylko kogo swym duchem Cyntyjus napuszył,

Teraz lada kto z nimi swata się po prostu;

Jeszcze nie umie kozie zawiązać i chwostu,

A już słowom ogony zawięzuje, na rzeczy

Nie znając się, jak sroka koło plotu skrzeczy.

Przetoż mądre Panienki, które tylko w trudnych

Wertepach i jaskiniach mieszkają nieludnych,

Brzydzą się nimi, że ich tajemnice skryte

Objawiają i czynią wszytkim pospolite.

A chociajże który $\mathrm{z}$ nich poniewolną weną

Sili się nad niechętną ku sobie kameną,

Chociaż i cudzej prace na pomoc zasiągnie,

Przecię nic, krom podmiotnych bęsiów nie wylągnie,

Które albo w pieluchach zła chwila podusi,

Że żaden z nich potomnej sławy nie zakusi,

Abo, jeśli do cudzych wpadną kiedy ręku,

W pogardzie ostatecznej zostaną bez wdzięku

Jak zatem widać, grafomanię na ogół identyfikowano z dyspozycjami osobowościowymi, a w każdym razie znacznie gorliwiej rozważano pierwszy element pary poeta - poemat. O WTÓRNOSCI wspomniał Potocki, ale mówił o „papugach”, czyli jednak autorach, nie wytworach [Moralia, $\mathrm{V}, 17]$. Wydaje się natomiast, że spośród cech utworu grafomańskiego najbardziej rzucal się w oczy mimowolny KOMIZM, utrwalony w popularnej anegdocie o tyranie sycylijskim Dionizjuszu Starszym. Przytoczył ją Lukian z Samosat:

Opowiadają także, że syrakuzański tyran Dionizjos napisał nad wyraz nędzną, wprost komiczną tragedię, z powodu której Filoksenos do kamieniołomów się dostał, ponieważ przy jej czytaniu nie mógł się wstrzymać od śmiechu. Otóż tyran, dowiedziawszy się, że ludzie wyśmiewają się z niego, kupił po długim poszukiwaniu tabliczkę, na której pisywał Aischylos, sądząc widocznie, że tabliczka będzie użyczać natchnień, wzlotów poetyckich i jemu także, podobnie jak tamtemu. Niestety, na tej tabliczce pisywal o wiele jeszcze większe głupstwa [...] [Do nieuka stosy ksiqg kupujqcego $]^{38}$.

Przed niezamierzoną śmiesznością przestrzegał dworzanina Łukasz Górnicki:

A jeśliby rozumiał (jakoż doma osądzić się każdemu trzeba), iż jego pisanie nie doszło tej doskonałości, żeby je ludzie radzi czytać i chwalić mieli, niechajże go światu nie ukazuje, aby z siebie nie uczynił śmiechu $[\ldots]^{39}$.

${ }^{38}$ Lukian z Samosat, Dialogi, t. 2, przeł. M.K. Bogucki, komentarzem opatrzył W. Madyda, Wrocław 1962, s. 315.

39 Tamże, s. 59. 
Podobnie Wacław Rzewuski [O nauce wierszopiskiej] przestrzegał niecierpliwych adeptów poezji przed wierszami, które łatwo mogą stać się pośmiewiskiem.

\section{5}

Na koniec chciałbym pokrótce przedstawić najważniejsze sposoby literackiej dykredytacji zjawiska. Po pierwsze, zaliczyłbym do nich parodystyczne wersje topiki metapoetyckiej i laudacyjnej. Ich uderzającą cechą jest uruchamianie wyobraźni po sarmacku rubasznej, nierzadko skatologicznej. Ofiara Andrzeja Krzyckiego [Apollo do czytelnika] przybywa nie z Helikonu, lecz chlewa. Tenże w inwektywie zatytułowanej Pewien poeta sprowokowany żalami Apollina i Rzeczypospolitej wybuchnąt takimi pochwatami pewnego dzieła pisał (załatwiając osobiste porachunki ze swym rywalem, Stanisławem Tarłą):

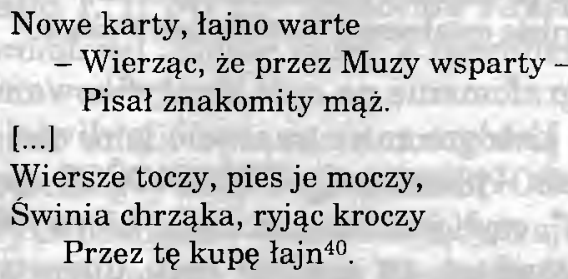

A w Wirydarzu poetyckim J.T. Trembeckiego znalazł się znany (później zresztą parafrazowany) wierszyk na poetę „niepewnego”:

Bodaj tego poetę Helikońską rosą

Muzy jego skropiły, co ją w kroku noszą 41

Nie mniej wyrazistych efektów poszukiwał Potocki we fraszce Do poetów teraźniejszych nieuków:

Poeci, których dzisia najobfitsze żniwo,

Gdy opłaźnie do wierszów rzuci się co żywo,

Że już ledwie nie baby owe pod kądzielą Albo za krosienkami na nie się ośmielą,

Pełne ich libraryje, pełne ich są druki, Równo puszy Apollo mądre i nieuki,

Tyle że różnym duchem: i u Apollina Jest natchnienie do wierszów, znajdzie się i bździna.

Nie dopiero to umie niecnotliwy bożek: Jednym poetom chucha, drugim pierdzi w rożek;

Prawdać, że to oboje odprawuje rymem:

40 Tamże, s. 91.

41 J.T. Trembecki, Wirydarz poetycki, t. 1, wydał A. Brückner, Lwów 1910, s. 122. 
Tamto pachnie, parnaskim a to śmierdzi dymem.

Insza pisać po składzie, insza wiersz nierówno.

I pomarańczać żółta, a wżdy gównem gówno ${ }^{42}$.

To bardzo reprezentatywny przykład: zauważalna dominacja obrazowania skatologicznego daje się objaśnić w kategoriach Bachtinowskiego karnawału i funkcji „dołu materialno-cielesnego”. Smród jest rewersem apollińskiego tchnienia, podobnie jak chlew - Helikonu, czy uryna źródła Hippokrene. Jak wskazywał Boileau, na skali wartości poetyckiej nie ma stopni pośrednich. Poeta i grafoman znajdują się na przeciwległych biegunach tej skali, a więc i biegunowe powinnny być ich atrybuty. Folgował sobie Krzycki czy Potocki, a i czarnoleskiej lipie opadły liście owiane smrodem, jaki bił od niewydarzonego poety [ $\mathrm{Na}$ lipę].

Następną metodą dyskredytacji, rozwiniętą w salonach stanisławowskich, były parodie twórczości grafomańskiej, uchodzące za jedną z bardziej atrakcyjnych form życia towarzyskiego. Pod imieniem Bielawskiego ogłaszali wiersze Dmochowski i prawdopodobnie Niemcewicz (F.K. Dmochowski parodystycznie, w imieniu Bielawskiego, odpowiedział na krytykę Juliana Niemcewicza). Drwili zeń Węgierski, Hulewicz, Stanisław Potocki, Wyszkowski, Minasowicz. Jego kosztem toczyli literackie pojedynki Trembecki i Węgierski, atakując go i koncypując - pod nazwiskiem Bielawskiego - nieudolne riposty43. Kajetana Jaksę Marcinkowskiego (zmarł on jako człowiek obłąkany) parodiował Cyprian Godebski.

Do tych praktyk prześmiewczych można włączyć parodystyczny koncept antykanonu, czyli, jak pisał Julian Tuwim, Parnasu postrzelonych ${ }^{44}$. Taki właśnie grafomański Parnas, z Bielawskim i Przybylskim na szczycie, wzniósł - na cześć nieszczęsnego Jaksy - generał Franciszek Morawski [Do milczqcego Jaksy]:

Sowo Minerwy, perlo Apollina, Szczytna topoli w poetów klombie, Ty, coś tak pięknie grywał nam sola

Na Feba trąbie!

Sławny pijaki krynic parnaskich,

Coś Bielawskiego, coś Jacka przepił,

Któż ci na wieczny smutek Morawskich

Gębę zalepił?

42 W. Potocki, Transakcja wojny chocimskiej $i$ inne utwory $z$ lat 1669-1680, słowem wstępnym poprzedziła B. Otwinowska, Warszawa 1987, s. 344.

43 Zob. J. Kott, Trembeciana, "Pamiętnik Literacki” 1950, z. 3-4.

44 Tamże, s. 114. 
Skądżeto, po tej bójce tak grackiej, Milczysz na wieczne dni mych zatrucie? Zapiej! ach zapiej! grzędy sarmackiej Sławny kogucie ${ }^{45}$ !

Zaiste, miał rację Montaigne: w każdej dziedzinie można sobie pozwolić na nieudolność, byle nie w poezji. Nie znalazł wielu naśladowców Horacy, który w przypływie wyrozumiałości pisał [List I, 1], że i ci ubodzy w talent autorzy są przecież pożyteczni, bo upowszechniają miłość do literatury i języka, że to $\mathrm{w}$ gruncie jest sympatyczne szaleństwo... Pisałem na początku, że grafomania sprawia wrażenie rodzinnego problemu samej literatury. Teraz można dodać: to zadawniona waśń i często - jak to domowy konflikt - bezwzględna.

${ }^{45}$ Cyt. za: W. Belza, op. cit., s. 135. 